\title{
Remote sensing as a tool to determine biophysical parameters of irrigated seed corn crop
}

\section{Sensoriamento remoto como ferramenta para determinação de parâmetros biofísicos da cultura do milho semente irrigado}

\author{
Robson Argolo dos Santos ${ }^{1 *}$; Jesiele Silva da Divincula ${ }^{2}$; Karine Rabelo de \\ Oliveira $^{3}$; Luan Peroni Venancio ${ }^{4}$; Marcos Francisco Missio ${ }^{5}$; Roberto Filgueiras ${ }^{4}$; \\ Fernando França da Cunha ${ }^{6}$; Catariny Cabral Aleman ${ }^{6}$
}

\section{Highlights:}

Remote sensing in estimating the actual evapotranspiration of the corn crop.

Estimation of dry biomass of the seed corn culture from the orbital remote sensing.

Efficiency of water use through water productivity estimated by remote sensing.

The high air temperature causes a reduction in the biomass accumulated during the day.

\begin{abstract}
In recent years, many studies have been conducted combining orbital remote sensing data and crop growth models for vegetation monitoring, evapotranspiration estimation and quantification of biophysical parameters, e.g., NDVI, surface temperature, albedo, and biomass. The aim of the present study was to estimate evapotranspiration (ETr), biomass (BIO), and water productivity (WP) for irrigated seed corn crop using the SAFER algorithm and Landsat 8 satellite images. For this, eight cloud-free images were acquired at different phenological stages over the interest area on the United States Geological Survey website and meteorological data. ETr was estimated by the SAFER algorithm, $\mathrm{BIO}$ by the Monteith model, and WP by the BIO/ETr ratio. ETr values ranged from 0 to $6 \mathrm{~mm} \mathrm{~d}^{-1}$, with the highest values coinciding with the period of high vegetative crop vigor, while the lowest values were found at the sowing season. The highest biomass values were observed from images at 46 and 62 days after sowing (DAS), corresponding to 286 and $289 \mathrm{~kg} \mathrm{ha}^{-1} \mathrm{~d}^{-1}$, respectively. The highest mean of water productivity was observed at $62 \mathrm{DAS}$, with $6.9 \mathrm{~kg} \mathrm{~m}^{-3}$ of water, corresponding to the period of maximum vegetative crop vigor. The application of the SAFER model together with Landsat 8 satellite images was an alternative to identifying the spatial and temporal variation of biophysical parameters of the corn crop. It could assist in the management of water in irrigated agriculture and decision making in large-sized farms.
\end{abstract}

Key words: Biomass. Evapotranspiration. Agricultural Management. Water Productivity. SAFER.

\footnotetext{
1 Discente do Curso de Doutorado do Programa de Pós-Graduação em Engenharia Agrícola, Universidade Federal de Viçosa, UFV, Viçosa, MG, Brasil. E-mail: argolo.agro@gmail.com

2 Discente do Curso de Doutorado do Programa de Pós-Graduação em Engenharia Agrícola, Universidade Federal Rural de Pernambuco, UFRPE, Recife, PE, Brasil. E-mail: jeeh.divincula@gmail.com

3 Enga Agrícola, UFV, Viçosa, MG, Brasil. E-mail: oliveirakr93@gmail.com

4 Drs., Programa de Pós-Graduação em Engenharia Agrícola, UFV, Viçosa, MG, Brasil. E-mail: 1pagronomo1990@gmail.com; betofilgueiras@gmail.com

5 Discente do Curso de Graduação em Agronomia, UFV, Viçosa, MG, Brasil. E-mail: marcos79missio@gmail.com

6 Profs. Drs., Departamento Engenharia Agrícola, UFV, Viçosa, MG, Brasil. E-mail: fernando.cunha@ufv.br; catariny@ufv.br

* Author for correspondence
} 


\section{Resumo}

Nos últimos anos, tem sido realizado muitos estudos que associam dados de sensoriamento remoto orbital e modelos de crescimento de cultura para fins de monitoramento da vegetação, estimativa de evapotranspiração e quantificação de parâmetros biofísicos, por exemplo o NDVI, temperatura da superfície, albedo, biomassa. O objetivo do presente estudo foi estimar a evapotranspiração (ETr), a biomassa (BIO) e a produtividade de água (PA) para a cultura do milho semente irrigado utilizandose o algoritmo SAFER e imagens do satélite Landsat 8. Para tal, foram adquiridas oito imagens, em diferentes fases fenológica, livre de nuvem sobre a área de interesse no site United States Geological Survey e dados meteorológicos. A ETr foi estimada por meio do algoritmo SAFER, a BIO pelo modelo de Monteith e a PA pela razão BIO/ETr. A ETr apresentou valores variando entre 0 e $6 \mathrm{~mm} \mathrm{~d}^{-1}$, sendo os maiores valores coincidentes com o período de maior vigor vegetativo da cultura e os menores com a época de semeadura. Os maiores valores de biomassa são notados nas imagens aos 46 e 62 dias após a semeadura (DAS), correspondendo a 286 e $289 \mathrm{~kg} \mathrm{ha}^{-1} \mathrm{~d}^{-1}$, respectivamente. A maior média da produtividade da água é observado aos $62 \mathrm{DAS}$, com $6,9 \mathrm{~kg} \mathrm{~m}^{-3}$ de água, correspondente ao período de máximo vigor vegetativo da cultura. A aplicação do modelo SAFER juntamente com imagens do Satélite Landsat 8 mostrou-se uma alternativa na identificação da variação espacial e temporal dos parâmetros biofísicos da cultura do milho, podendo auxiliar no manejo da água na agricultura irrigada e na tomada de decisão em propriedades agrícolas de grande porte.

Palavras-chave: Biomassa. Evapotranspiração. Manejo Agrícola. Produtividade da água. SAFER.

\section{Introduction}

Corn (Zea mays L.) is one of the main crops in the Brazilian and world scenario, which is partially due to its versatility of use in animal production and human consumption, improving economic and social aspects. Brazil is one of the world's largest corn producers and had high productivity growth between 1985 and 2018. According to historical data from CONAB (Companhia Nacional de Abastecimento [CONAB], 2019), its mean productivity was equivalent to $1,549 \mathrm{~kg} \mathrm{ha}^{-1}$ in 1985 and $4,857 \mathrm{~kg} \mathrm{ha}^{-1}$ in 2018, i.e., there was an increase of the mean productivity at a ratio of $213 \%$.

The genetic factor is one of the main technologies to obtain high corn productivity tecnologia (Hall \& Richards, 2013), which can be potentiated by correct irrigation management. Thus, the use of good quality seeds is essential to the success of the crop. Seed production is usually performed between the patent-holding company and the producer in a mutual gain association. All the appropriate crop management is carried out on the rural property, including water application via irrigation.
Irrigation is arguably of great importance for achieving high-quality seed productivities. However, it is one of the largest consumers of all water used, mainly when proper management is not adopted. According to Kamali and Nazari (2018), more than half of the water is lost unused by plants in a poorly managed irrigation system, generating economic costs to the producer, environment, and even social conflicts over water use. Thus, the management of these resources becomes essential in the production process.

The use of evapotranspiration to quantify water demand is one of the most economically viable strategies for management in irrigated areas. Also, remote sensing is an excellent tool for measuring the amount of water evapotranspirated by the crop. This quantification can be carried out using the Simple Algorithm For Evapotranspiration Retrieving (SAFER), developed by Teixeira (2010), which measures evapotranspiration through NDVI biophysical parameters, surface temperature, and surface albedo. The use of satellite remote sensing techniques and applications of energy balance models together with agrometeorological 
information allow mapping biophysical parameters and obtaining biomass production (BIO) and water productivity (WP) values in agricultural and environmental systems (Teixeira, Bastiaanssen, Ahmad, \& Bos, 2009).

$\mathrm{BIO}$ is related to photosynthetically active radiation and is a measure to assess the ability to produce dry matter of a particular plant species by the photosynthetic process that converts solar energy into biomass. The model developed by Monteith (1972) and consolidated by Bastiaanssen and Ali (2003) has been a very effective tool to determine the daily increment of biomass.

Water productivity (WP) expresses how much of a product results from the application of one unit of water used in the production process (Mdemu, Rodgers, Vlek, \& Borgadi, 2009). In the context of agricultural production, WP can be obtained by the relationship between $\mathrm{BIO}$ and the amount of water used, being quantified by the SAFER algorithm (Teixeira, 2010; Teixeira \& Leivas, 2017).
Thus, this study aimed to estimate evapotranspiration, biomass, and water productivity for irrigated seed corn crop using the SAFER algorithm and Landsat 8 satellite images for irrigation management decision-making.

\section{Material and Methods}

The study area comprises the rural property Modelo, located in Luís Eduardo Magalhães, western Bahia State, Brazil (Figure 1). The coordinate point at the center of the property is $378892.04 \mathrm{E}$ and 8633485.05 S at Universal Transverse Mercator (UTM) projection in zone $23 \mathrm{~S}$ and elevation of $852 \mathrm{~m}$. The property grows soybean, seed corn, bean, and pumpkin under rainfed and irrigated systems. Irrigation is performed by seven center pivot equipment with an individual area of 80 ha. The pivot number 3 (Figure 1) was chosen for the present study because of the high quantity of cloudfree images on it.

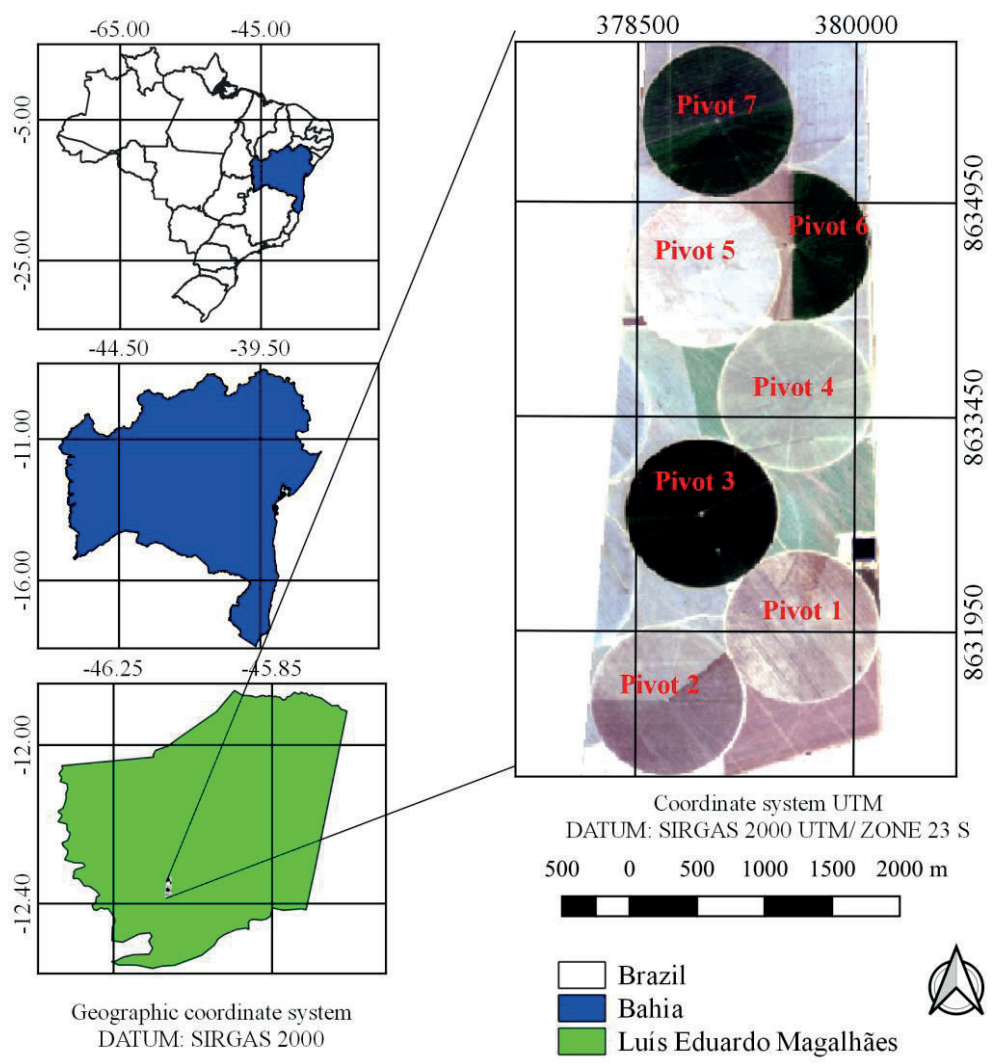

Figure 1. Location of the study area and identification of the location of the center pivots on the farm. 
The local climate is classified as tropical (Aw), according to the Köppen classification (Alvares, Stape, Sentelhas, Moraes Gonçalves, \& Sparovek, 2013). The mean annual maximum and minimum temperatures are 33 and $20{ }^{\circ} \mathrm{C}$, respectively, with annual mean precipitation of $1250 \mathrm{~mm}$, distributed from November to March and drought periods from April to September (Instituto Nacional de Meteorologia [INMET], 2018).

Eight cloud-free images over the area of interest were acquired on the United States Geological Survey (USGS) website from the sensors operational land imager (OLI) and thermal infrared sensor (TIRS) onboard the Landsat 8 satellite to estimate the biophysical parameters of the irrigated area. All images are from 2017, the first was taken for June 15,2017 , and the others with a temporal resolution of 16 days until the end of the crop cycle on October 5, 2017, corresponding to 14 and 126 DAS (days after sowing), respectively. During this period, there are droughts in the region, demanding more water applied via irrigation.

Atmospheric correction and radiometric calibration operations were performed after image acquisition using the plugin for the software QGis $^{\circledR}$.2.18 DOS 1 (Dark Object Subtraction). Then, the mean values of the biophysical parameters that compose the real evapotranspiration, that is, the top-of-atmosphere albedo $\left(\alpha_{T O A}\right)$, sensor brightness temperature $\left(T_{\text {bri }}\right)$, surface albedo $\left(\alpha_{0}\right)$, surface temperature $\left(\mathrm{T}_{0}\right)$, and normalized difference vegetation index (NDVI), were extracted.

The estimates of biophysical parameters in the SAFER followed the methodology of Teixeira (2010), where the surface albedo $\left(\alpha_{0}\right)$ is obtained from the top-of-atmosphere albedo $\left(\alpha_{T O A}\right)$ by Equations (1) and (2):

$$
\begin{aligned}
& \alpha_{T O A}=0.300 \rho_{2}+0.277 \rho_{3}+0.233 \rho_{4}+0.143 \rho_{5}+0.036 \rho_{6}+0.012 \rho_{7} \\
& \alpha_{0}=a \times \alpha_{T O A}+b
\end{aligned}
$$

where $a$ and $b$ are the regression coefficients, with values of 0.7 and 0.006 , respectively, and $\rho_{2}$, $\rho_{3}, \rho_{4}, \rho_{5}, \rho_{6}$, and $\rho_{7}$ are the surface reflectances of bands $2,3,4,5,6$, and 7 , respectively. The weights adopted for each band of the Landsat 8 satellite were determined by Silva et al. (2016).

Sensor brightness temperature $\left(\mathrm{T}_{\text {bri }}\right)$ and surface temperature $\left(\mathrm{T}_{0}\right)$, both in $\mathrm{K}$, are given by Equations (3) and (4), respectively:

$$
\begin{aligned}
& \mathrm{T}_{\mathrm{bri}}=\rho_{10}+273.16 \\
& \mathrm{~T}_{0}=1.11 \times \mathrm{T}_{\mathrm{bri}}-31.89
\end{aligned}
$$

where $\rho_{10}$ is the thermal infrared band of the Landsat 8 TIRS sensor.

NDVI was estimated by Equation (5):

$$
\mathrm{NDVI}=\frac{\rho_{\mathrm{IR}}-\rho_{\mathrm{R}}}{\rho_{\mathrm{IR}}+\rho_{\mathrm{R}}}
$$

where $\rho_{\mathrm{IR}}$ is the near-infrared reflectance (band 5) and $\rho_{R}$ is the red reflectance (band 4).

The relationship between real evapotranspiration and reference evapotranspiration (ETr/ETo) was obtained with the data of $\alpha_{0}, T_{0}$, and NDVI, being calculated in the SAFER by Equation (6):

$$
\frac{\mathrm{ETr}}{\mathrm{ET}_{\mathrm{o}}}=\exp \left[a+b\left(\frac{\mathrm{T}_{0}}{\alpha_{\mathrm{o}} \times \mathrm{NDVI}}\right)\right]
$$

where $a$ and $b$ are the calibration coefficients obtained by the model of Teixeira (2010), with values of 1.8 and -0.008 , respectively, for the semiarid region.

Reference evapotranspiration (ETo, $\mathrm{mm} \mathrm{d}^{-1}$ ) was determined by the Penman-Monteith method (Allen, Pereira, Raes, \& Smith, 1998), using the data from the weather station of Luis Eduardo Magalhães, located, approximately, at $35 \mathrm{~km}$ from the study area. 
The real evapotranspiration $\left(\mathrm{ETr}, \mathrm{mm} \mathrm{d}^{-1}\right)$ of the irrigated area was estimated from the data of ETo and the ETr/ETo ratio, according to Equation (7):

$$
\mathrm{ETr}=\frac{\mathrm{ETr}}{\mathrm{ET}_{\mathrm{o}}} \times \mathrm{ET}_{\mathrm{o}}
$$

Biomass production per unit area over time was calculated using the radiation model developed by Monteith (1972).

$$
\mathrm{BIO}=\varepsilon_{\max } \times E_{f} \times \mathrm{APAR} \times 0.864
$$

where BIO is the biomass in $\mathrm{kg} \mathrm{ha}^{-1} \mathrm{~d}^{-1}, \varepsilon_{\max }$ is the maximum radiation use efficiency, with a value of $2.7 \mathrm{~g} \mathrm{MJ}^{-1}$ for the corn crop (Bastiaanssen \& Ali, 2003), $\mathrm{E}_{\mathrm{f}}$ is the evaporative fraction (Teixeira, Leivas, Andrade, \& Hernandez, 2015), and APAR is the absorbed photosynthetically active radiation (W $\mathrm{m}^{-2}$ ). The evaporative fraction is the ETr/ETo ratio estimated from the SAFER model described above.

APAR is a fraction of photosynthetically active radiation (PAR) obtained by the values of NDVI and incident daily solar radiation $(\mathrm{Rg})$ (Asrar, Myneni, \& Choudhury, 1992; Hatfield, Asrar, \& Kanemasu, 1984; Moran, Maas, \& Pinter, 1995), which is calculated by:

$$
\mathrm{APAR}=(1.26 \times \mathrm{NDVI}-0.16) \times(0.48 \times \mathrm{Rg})
$$

Finally, water productivity $\left(\mathrm{kg} \mathrm{m}^{-3}\right)$, i.e., the amount of biomass that can be produced for each $1 \mathrm{~m}^{3}$ of water and that provides information on water use efficiency (WUE) by plants (Coaguila, Hernandez, Teixeira, Franco, \& Leivas, 2017; Teixeira et al., 2015) was estimated by Equation (10):

$$
\mathrm{WP}=\frac{\mathrm{BIO}}{\mathrm{ETr}} \times 0.10
$$

\section{Results and Discussion}

Table 1 shows the meteorological data acquired on the date of the Landsat 8 satellite passage in a 16-day interval beginning at 14 days after sowing (DAS). The highest maximum and minimum temperature values were recorded at 126 DAS, while the lowest values were recorded at 46 and 62 DAS, respectively. The highest thermal amplitude was recorded at $78 \mathrm{DAS}$, the period of a high degree of crop development. Moisture values below $60 \%$ were also observed, with maximum values at 96 DAS and minimum values at 126 DAS, the end of the crop cycle. Wind speed values registered the minimum at 62 DAS and the maximum at 96 DAS. There was an increase in radiation values up to 110 DAS, which had a high value of incident solar radiation $(\mathrm{Rg})$. The mentioned parameters influence the reference evapotranspiration, which presented high values at 110 and $126 \mathrm{DAS}$, the period of crop senescence. The evaporative fraction (ETr/ETo) showed a high value at 46 DAS and then decreased. The evaporative fraction at 78 DAS was below normal for the crop cycle period, being influenced by daily weather conditions.

The biophysical parameters required to enter the SAFER algorithm are shown in Table 2. According to Teixeira and Leivas (2017), surface albedo, NDVI, and surface temperature influence water and vegetation variables in different agroecosystems. NDVI enables the knowledge of water conditions and crop development stage. Albedo is related to the balance of energy absorbed and reflected by a target. In the case of vegetation, the high the vigor, the high the energy absorbed. Surface temperature is related to the surface longwave emission that is influenced by the water content in the soil or plant (Gomes, Silva, Cavalcanti, \& Rocha, 2009; Teixeira \& Leivas, 2017). 
Table 1

Weather variables acquired on the dates of image acquisition using the Landsat 8 satellite

\begin{tabular}{lccccccc}
\hline DAS & $\begin{array}{c}\text { Tmax } \\
{ }^{\circ} \mathrm{C}\end{array}$ & $\begin{array}{c}\text { Tmin } \\
{ }^{\circ} \mathrm{C}\end{array}$ & $\begin{array}{c}\mathrm{RH} \\
\%\end{array}$ & $\begin{array}{c}\mathrm{U}_{2} \\
\mathrm{~m} \mathrm{~s}^{-1}\end{array}$ & $\begin{array}{c}\mathrm{R}_{\mathrm{G}} \\
\mathrm{W} \mathrm{m}^{-2}\end{array}$ & $\begin{array}{c}\text { ETo } \\
\mathrm{mm} \mathrm{d}^{-1}\end{array}$ & \begin{tabular}{c} 
ETr/ETo \\
\hline 14
\end{tabular} \\
30 & 30.2 & 13.3 & 53.0 & 4.0 & 231.80 & 5.8 & 0.05 \\
46 & 29.7 & 14.6 & 50.5 & 3.0 & 234.95 & 5.2 & 0.5 \\
62 & 29.1 & 11.7 & 57.5 & 3.2 & 242.80 & 5.1 & 1.18 \\
78 & 29.9 & 10.5 & 54.0 & 1.7 & 249.65 & 4.5 & 1.10 \\
96 & 33.6 & 11.9 & 43.0 & 2.3 & 263.90 & 6.0 & 0.65 \\
110 & 29.4 & 15.7 & 58.0 & 5.2 & 282.40 & 6.6 & 0.80 \\
126 & 32.5 & 15.9 & 45.0 & 4.0 & 300.90 & 7.7 & 0.50 \\
\hline
\end{tabular}

DAS: days after sowing; Tmax: maximum temperature; Tmin: minimum temperature; $R H$ : relative humidity; $\mathrm{U}_{2}$ : wind speed at 2 $\mathrm{m}$ height; $\mathrm{R}_{\mathrm{G}}$ : incident solar radiation; ETo: reference evapotranspiration.

Table 2

Daily mean values and standard deviation of surface albedo $\left(\alpha_{0}\right)$, normalized difference vegetation index (NDVI), and surface temperature $\left(T_{0}\right)$ obtained at different periods of seed corn crop development

\begin{tabular}{cccc}
\hline DAS & $\boldsymbol{\alpha}_{0}$ & NDVI & $\mathrm{T}_{0}$ \\
\hline 14 & $0.17 \pm 0.010$ & $0.28 \pm 0.03$ & $26.8 \pm 1.4$ \\
30 & $0.14 \pm 0.004$ & $0.57 \pm 0.05$ & $24.3 \pm 0.7$ \\
46 & $0.12 \pm 0.001$ & $0.79 \pm 0.03$ & $22.6 \pm 0.7$ \\
62 & $0.12 \pm 0.004$ & $0.81 \pm 0.02$ & $24.1 \pm 0.8$ \\
78 & $0.12 \pm 0.001$ & $0.76 \pm 0.03$ & $26.9 \pm 0.9$ \\
96 & $0.14 \pm 0.003$ & $0.72 \pm 0.03$ & $24.8 \pm 0.8$ \\
110 & $0.15 \pm 0.004$ & $0.58 \pm 0.04$ & $28.8 \pm 0.7$ \\
126 & $0.16 \pm 0.005$ & $0.50 \pm 0.06$ & $29.1 \pm 1.3$ \\
\hline
\end{tabular}

DAS: days after sowing.

Table 2 shows the variation of parameters assessed along the phenological cycle of the crop, influenced by the degree of corn development. The highest albedo and lowest NDVI values were recorded at 14 DAS. It occurred because plants were at the beginning of growth, covering only a small percentage of the soil. Thus, the latter presented a large exposed area, favoring a low energy absorption by plants. Conversely, the lowest albedo values were observed between 46 and 78 DAS. At this time, the corn plant was increasing the leaf area and incorporating biomass. Peng et al. (2015) state that the increase in leaf area causes an increase in the energy interception by the vegetation canopy, reducing the energy absorbed by the soil due to a high vegetation cover. According to $\mathrm{Wu}$ et al. (2017), the dynamics of soil cover and crop phenological stage lead to a variation in albedo seasonality, as shown in Table 2.

NDVI values had inverse behavior to albedo. The low value of this index at 14 DAS was influenced by the low vegetation density. However, it increased at 30 DAS due to corn growth and development. On subsequent dates, NDVI continued to increase until it reached a peak of 0.81 . This behavior is due to the maximum crop growth and development when 
the photosynthetic rate is potentiated. The pigments responsible for photosynthesis absorb the visible radiation with high efficiency, especially the red wavelength, while there is low absorption of the near-infrared wavelength by spongy mesophyll cell structures (Toureiro, Serralheiro, Shahidian, \& Sousa, 2017).

NDVI values decreased at $78 \mathrm{DAS}$. This behavior occurred because the plant reached its maximum vegetative stage and started the reproductive stage, with nutrient and water displacement to reproductive organs and later onset of senescence. The mentioned authors assessed the irrigation management using remote sensing and found the highest NDVI value at 80 DAS for the corn crop, which is close to that found in this study, but decreased soon after. These authors emphasized that the ability of NDVI to detect crop senescence is important for irrigation management, which can be interrupted at this phenological stage.

Table 2 also shows variations in surface temperature values throughout the crop cycle, influenced by weather conditions and corn crop management. The highest surface temperature value was recorded at 78 DAS caused by weather conditions and evidencing water stress in the crop. Gomes et al. (2009) worked in the region of Santa Rita do Passa Quatro, SP, Brazil, and found values between 20.0 and $24.1^{\circ} \mathrm{C}$ for irrigated crop areas, but this parameter is dependent on other weather factors and not only on irrigation management, as shown in Table 2.

According to Teixeira and Leivas (2017), parameters obtained by remote sensing in irrigated crops are also directly affected by irrigation management. Real crop evapotranspiration (ETr) in these areas is influenced by both crop and irrigation management and weather conditions, especially incident solar radiation.

Figure $2 \mathrm{a}$ shows the spatial and temporal variation of the ETr of seed corn, estimated by the SAFER algorithm. The values ranged from 0 to 6 $\mathrm{mm} \mathrm{d}^{-1}$, with the highest means of ETr found at 46, 62, and 96 DAS and the lowest at 14 DAS.
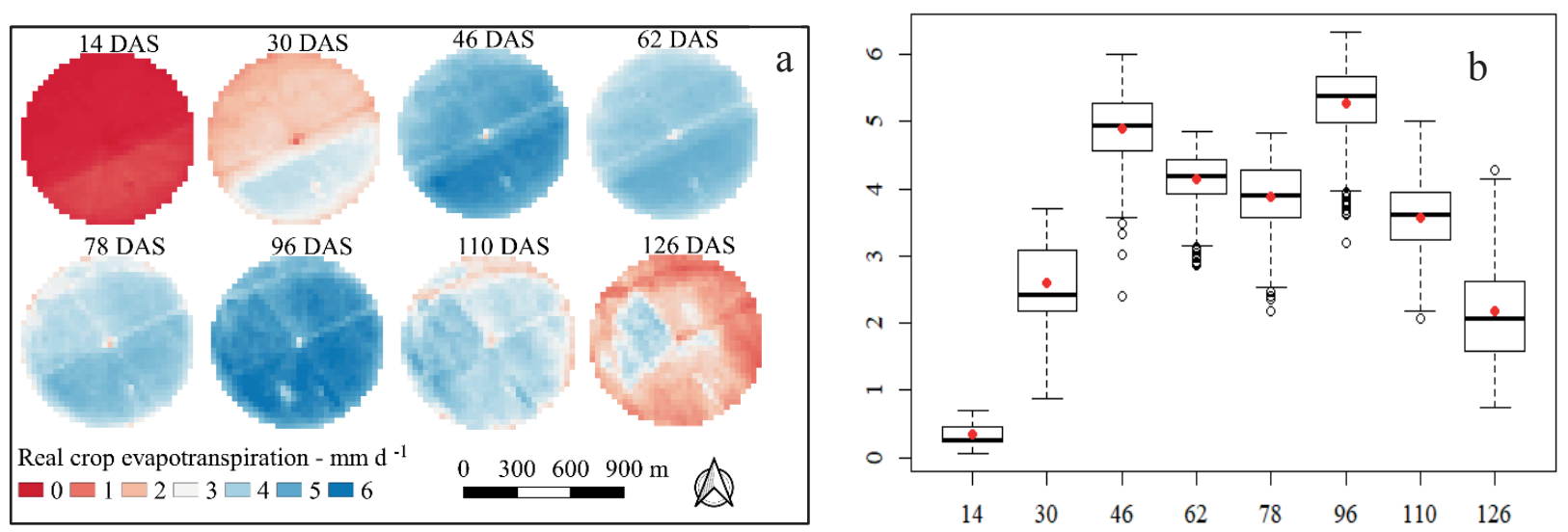

Figure 2. Spatiotemporal variation map (a) and boxplot graph (b) of the real evapotranspiration (ETr) obtained by the SAFER algorithm at different periods of seed corn crop development.

The highest ETr occurred at 96 DAS, being influenced by the high ETo of that day associated with NDVI and albedo values. The second highest ETr value occurred at 46 DAS, a period in which the crop showed high vegetative vigor, evidenced by $\alpha_{0}$ and NDVI (high photosynthetic rate) and reference evapotranspiration of the day $(5.1 \mathrm{~mm})$. Although presenting NDVI values at 62 DAS higher than 46 DAS, a low contribution was observed from ETo $(4.5 \mathrm{~mm})$ and $\mathrm{T}_{0}$, both influencing $\mathrm{ETr}$ 
by the SAFER model. Therefore, the real crop evapotranspiration is related to both intrinsic plant and weather conditions.

The seed corn crop presented a high development in the southern part of the center pivot at 30 DAS (Figure 2a), showing higher evapotranspiration than that of the northern part, caused by the different sowing dates. Low spatial variability of crop evapotranspiration was observed at 78 DAS when the soil was completely covered with vegetation, but a low ETr compared to days of high crop development, possibly influenced by irrigation management. The coefficient of evaporation is drastically reduced when soil is fully covered, being transpiration the main component that raises ETr. A reduction in ETr was observed from 110 DAS because the plant goes into the senescence stage during this period and irrigation is interrupted, leading to low soil water associated with the death of plant organs and consequent reduction of crop evapotranspiration. The lowest ETr values were found at 14 DAS, i.e., the beginning of the germination stage, which presented values close to zero due to soil exposure, low plant density, and low applied water depth.

Figure $2 \mathrm{~b}$ shows the behavior of ETr, with values concentrated in the second and third quartiles, with a mean close to the median. A lower variation was observed at 62 DAS than the other days, but with outliers. Outliers were also observed at 46, 78, and
96 DAS. These outliers can be explained by the variability present in the cultivated area and/or poor distribution of water by irrigation equipment. The center pivot of the studied property applies the same irrigation depth in the cultivated area, i.e., the area under the equipment is considered homogeneous. However, cultivated areas usually vary widely for soil type and texture and crop development. Therefore, the application of a uniform irrigation depth to the entire area under the center pivot may have been favorable in a region or even an excess or deficit in others, causing variability.

Biomass (BIO) is dependent on incident solar radiation $(\mathrm{Rg})$, vegetation, carbon dioxide, and available soil water (Taiz, Zeiger, Moller, \& Murphy, 2017; Teixeira et al., 2015). Figure 3 shows an evolution in BIO increase until the stabilization period, which occurs during the reproductive stage. Then, its values decrease due to corn maturation. The first two images of the crop cycle present low biomass (BIO) value due to the low carbon absorption capacity as a function of the lower photosynthetic activity, evidenced by high albedo and low NDVI (Table 2). The highest increment of biomass values was verified at 46 and 62 DAS, corresponding to 286 and $289 \mathrm{~kg} \mathrm{ha}^{-1} \mathrm{~d}^{-1}$, respectively. In addition to high NDVI values, $\mathrm{Rg}$ values equivalent to 242.8 and $249.65 \mathrm{~W} \mathrm{~m}^{-2}$ were recorded during these days, influencing the fraction of photosynthetically active radiation and causing high daily biomass accumulation.
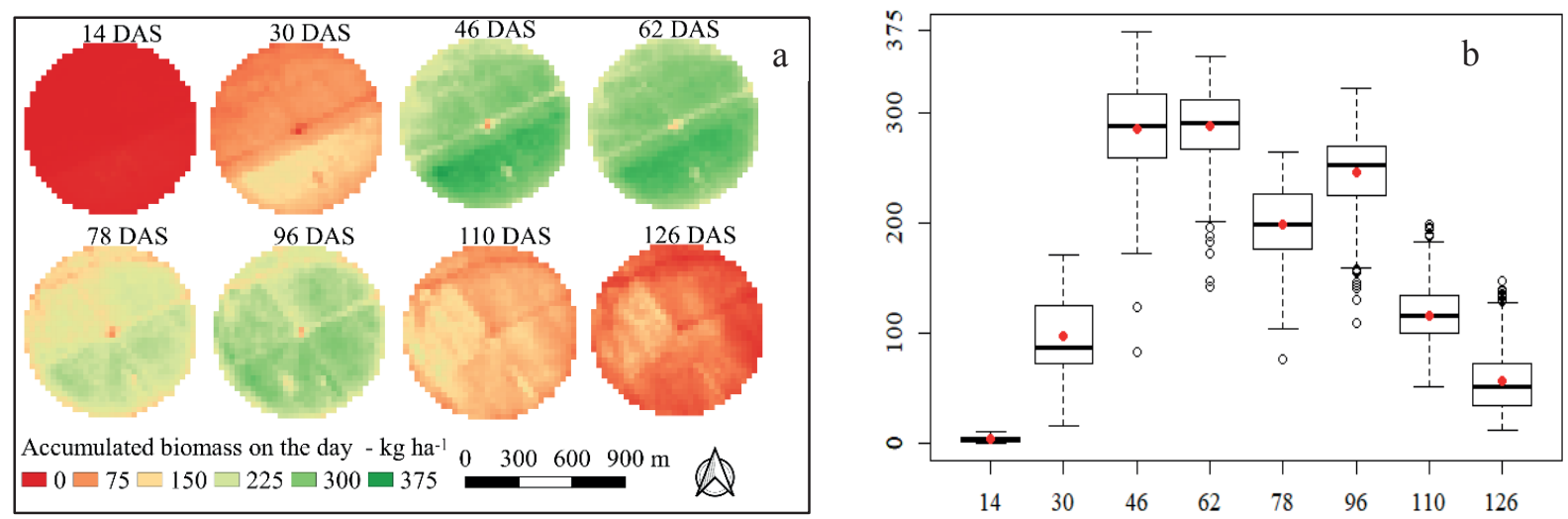

Figure 3. Spatiotemporal variation map (a) and boxplot graph (b) of the real biomass (BIO) obtained by the SAFER algorithm at different periods of seed corn crop development. 
Another factor that influences biomass increment according to the methodology of Monteith (1972) is the evaporative fraction, which is the relationship between the reference evapotranspiration and the real crop evapotranspiration (Yuan et al., 2013). BIO decreased at 78 DAS due to high air temperatures, which increased the surface temperature. According to Carroll, Hansen, Hopkins and DeJonge (2017), canopy temperature increases with increasing ambient air temperature and sunlight intensity due to the high absorption of solar radiation by the leaf. Lizaso et al. (2017) reported that thermal stress causes a reduction in biomass due to stomatal closure and low $\mathrm{CO}_{2}$ absorption. A maximum temperature of $33.6{ }^{\circ} \mathrm{C}$ was recorded at 78 DAS. The ideal temperature for corn is around $30{ }^{\circ} \mathrm{C}$ (Parent \& Tardieu, 2012; Wang et al., 2018; Yan \& Hunt, 1999). However, there are divergences in these values. Although irrigation benefits the crop, the soil is not constantly under field capacity, and a low variation in soil water content associated with high temperature causes stomatal closure, a plant defense mechanism, thus leading to a reduction of BIO.

The inverse process occurred after sixteen days, i.e., the highest biomass value was recorded at that time. This increase is due to a reduction in air temperature, which caused a decrease in surface temperature (Table 2) and increased the evaporative fraction (Table 1), calculated by SAFER. The evaporative fraction is directly proportional to the BIO equation established by Monteith (1972) and applied by Teixeira et al. (2015). Thus, the surface temperature had high weight in the evaporative fraction calculation, reducing the effects of NDVI and albedo, parameters used in the Teixeira (2010) model, providing higher $\mathrm{BIO}$ values for this day. A reduction in biomass increment due to plant senescence was observed from 110 DAS.

Figure $3 \mathrm{~b}$ shows that the highest $\mathrm{BIO}$ value was recorded at 46 DAS, with variations in values as a function of crop management and irrigation. As observed in ETr, most values are concentrated in the second and third quartiles, with the mean close to the median, showing a normality behavior of the data despite the outliers evidenced by management.

Figure 4 shows spatial and temporal variations in water productivity (WP). These variations in WP are high at times when the highest BIO (Figure 3) and lowest ETr (Figure 2) occurred. The highest mean of WP was observed at 62 DAS, with a mean value of $6.9 \mathrm{~kg}$ of biomass for $1 \mathrm{~m}^{3}$ of water, i.e., the irrigation provided higher conversion of the applied water into dry matter. The high WP value was due to the high vegetative vigor of plants, a period in which the metabolic physiology has the highest efficiency in carbon dioxide conversion. The lowest WP values were observed at 14, 110, and 126 DAS. The irrigated plants had low carbon conversion efficiency in the photosynthetic system after sowing and seedling emergence (14 DAS). However, at 110 and 126 DAS, the crop is at the end of its cycle, and irrigation is interrupted, causing a reduction of the efficiency of carbon absorption due to the death of plant organs influenced by senescence.
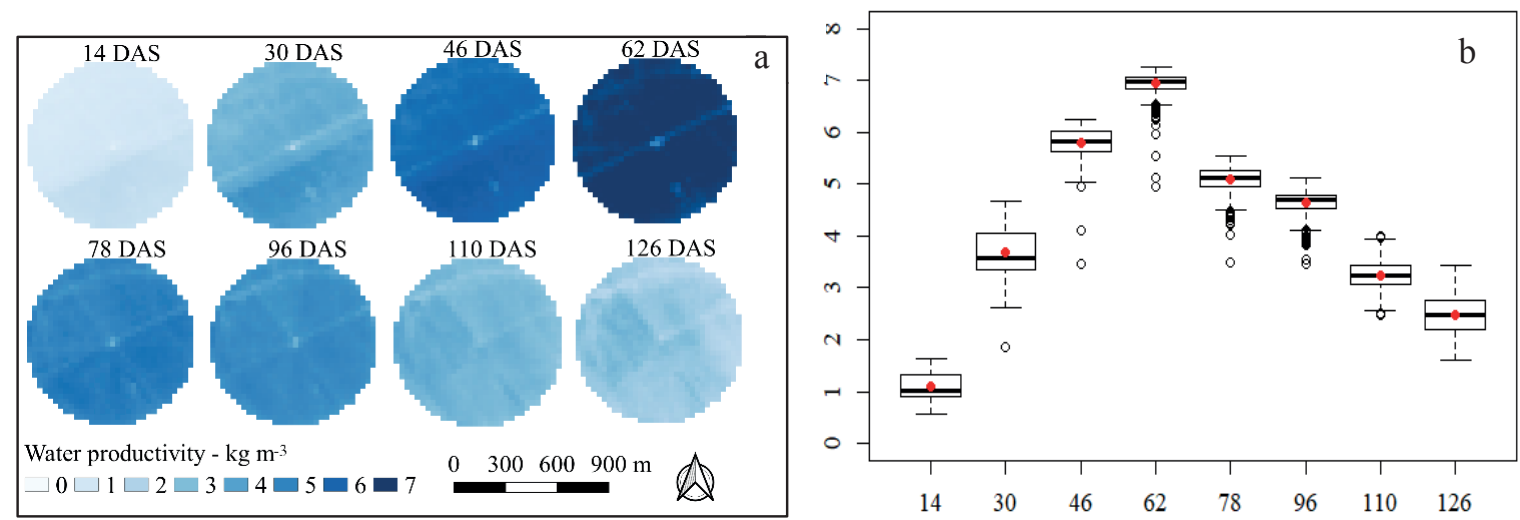

Figure 4. Spatiotemporal variation map (a) and boxplot graph (b) of the water productivity obtained by the SAFER algorithm at different periods of seed corn crop development. 
Figure $4 \mathrm{~b}$ shows an increase in water productivity until it reaches its maximum value, with a subsequent decrease. Different from the figures above, the pixels for WP presented the lowest variation where there is the highest concentration of values (second and third quartiles). However, WP presented a high number of outliers caused by the unevenness of the irrigated crop, especially on the day when it had the highest development.

The use of remote sensing in agriculture, especially the irrigated agriculture, is an alternative to analyze and quantify parameters of evapotranspiration, biomass accumulation, and water productivity in the cultivated area.

\section{Conclusions}

Orbital sensors allow measuring the daily increment of dry matter in the irrigated seed corn crop.

High values of surface temperature negatively affect the biomass of the corn crop, while high NDVI and low albedo values have a positive influence on this biomass.

Water productivity tends to be high when the plant is at its maximum biomass increment and with less evapotranspiration.

Estimating the real crop evapotranspiration from sensors embedded in satellites is an important tool in irrigation management decision-making, and it is possible to apply irrigation management from remote sensing.

\section{Acknowledgments}

To the Coordination for the Improvement of Higher Education Personnel (CAPES) for granting the scholarships to the first, second, and third authors.

\section{References}

Allen, R. G., Pereira, L. S., Raes, D., \& Smith, M. (1998). Crop evapotranspiration - Guidelines for computing crop water requirements - FAO Irrigation and drainage paper 56 (9nd ed.). Rome: Food and Agriculture Organization of the United Nations.

Alvares, C. A., Stape, J. L., Sentelhas, P. C., Moraes Gonçalves, J. L. de, \& Sparovek, G. (2013). Köppen's climate classification map for Brazil. Meteorologische Zeitschrift, 22(6), 711-728. doi: 10.1127/0941-2948/2013/0507

Asrar, G., Myneni, R. B., \& Choudhury, B. J. (1992). Spatial heterogeneity in vegetation canopies and remote sensing of absorbed photosynthetically active radiation: a modeling study. Remote Sensing of Environment, 41(2-3), 85-103. doi: 10.1016/00344257(92)90070-Z

Bastiaanssen, W. G. M., \& Ali, S. (2003). A new crop yield forecasting model based on satellite measurements applied across the Indus Basin, Pakistan. Agriculture, Ecosystems and Environment, 94(3), 321-340. doi: 10.1016/S0167-8809(02)00034-8

Carroll, D. A., Hansen, N. C., Hopkins, B. G., \& DeJonge, K. C. (2017). Leaf temperature of maize and Crop Water Stress Index with variable irrigation and nitrogen supply. Irrigation Science, 35(6), 549560. doi: 10.1007/s00271-017-0558-4

Coaguila, D. N., Hernandez, F. B. T., Teixeira, A. H. de C., Franco, R. A. M., \& Leivas, J. F. (2017). Water productivity using SAFER - Simple Algorithm for Evapotranspiration Retrieving in watershed. Revista Brasileira de Engenharia Agrícola e Ambiental, 21(8), 524-529. doi: 10.1590/1807-1929/agriambi. v2 1 n8p $524-529$

Companhia Nacional de Abastecimento (2019). Milho. Recuperado de https://www.conab.gov.br/info-agro/ safras/serie-historica-das-safras?start $=20$

Gomes, B. da, Silva, B. B, Cavalcanti, E. P., \& Rocha, H. R. (2009). Balanço de radiação em diferentes biomas no estado de São Paulo mediante imagens landsat 5. Geociencias, 28(2), 153-164.

Hall, A. J., \& Richards, R. A. (2013). Prognosis for genetic improvement of yield potential and water-limited yield of major grain crops. Field Crops Research, 143(3), 18-33. doi: 10.1016/j.fcr.2012.05.014

Hatfield, J. L., Asrar, G., \& Kanemasu, E. T. (1984). Intercepted photosynthetically active radiation estimated by spectral reflectance. Remote Sensing of Environment, 14(1-3), 65-75. doi: 10.1016/00344257(84)90008-7 
Instituto Nacional de Meteorologia (2018). Normais climatológicas (1961-2018). Recuperado de http:// www.inmet.gov.br/portal/index.php?r=clima/ normaisClimatologicas

Kamali, M. I., \& Nazari, R. (2018). Determination of maize water requirement using remote sensing data and SEBAL algorithm. Agricultural Water Management, 209(10), 197-205. doi: 10.1016/j. agwat.2018.07.035

Lizaso, J. I., Ruiz-Ramos, M., Rodríguez, L., GabaldonLeal, C., Oliveira, J. A., Lorite, I. J.,... Otegui, M. E. (2017). Modeling the response of maize phenology, kernel set, and yield components to heat stress and heat shock with CSM-IXIM. Field Crops Research, 214(12), 239-254. doi: 10.1016/j.fcr.2017.09.019

Mdemu, M. V., Rodgers, C., Vlek, P. L. G., \& Borgadi, J. J. (2009). Water productivity (WP) in reservoir irrigated schemes in the upper east region (UER) of Ghana. Physics and Chemistry of the Earth, 34(4-5), 324-328. doi: 10.1016/j.pce.2008.08.006

Monteith, J. L. (1972). Solar radiation and productivity in tropical ecosystems. Journal of Applied Ecology, 9(3), 747-766. doi: 10.2307/2401901

Moran, M. S., Maas, S. J., \& Pinter, P. J. (1995). Combining remote sensing and modeling for estimating surface evaporation and biomass production. Remote Sensing Reviews, 12(3-4), 335353. doi: 10.1080/02757259509532290

Parent, B., \& Tardieu, F. (2012). Temperature responses of developmental processes have not been affected by breeding in different ecological areas for 17 crop species. New Phytologist, 194(3), 760-774. doi: 10.1111/j.1469-8137.2012.04086.x

Peng, J., Fan, W., Xu, X., Wang, L., Liu, Q., Li, J., \& Zhao, P. (2015). Estimating crop Albedo in the application of a physical model based on the law of energy conservation and spectral invariants. Remote Sensing, 7(11), 15536-15560. doi: 10.3390/ rs 71115536

Silva, B. B. da, Braga, A. C., Braga, C. C., Oliveira, L. M. M. de, Montenegro, S. M. G. L., \& Barbosa, B., Jr. (2016). Procedures for calculation of the albedo with OLI-Landsat 8 images: Application to the Brazilian semi-arid. Revista Brasileira de Engenharia Agrícola e Ambiental, 20(1), 3-8. doi: 10.1590/1807-1929/agriambi.v20n1p3-8

Taiz, L., Zeiger, E., Moller, I. M., \& Murphy, A. (2017). Fisiologia e desenvolvimento vegetal (6a ed.). Porto Alegre, RS: Artmed.
Teixeira, A. H. de C. (2010). Determining regional actual evapotranspiration of irrigated crops and natural vegetation in the São Francisco River Basin (Brazil) Using remote sensing and penman-monteith equation. Remote Sensing, 2(5), 1287-1319. doi: $10.3390 / \mathrm{rs} 0251287$

Teixeira, A. H. de C., Bastiaanssen, W. G. M., Ahmad, M. D., \& Bos, M. G. (2009). Reviewing SEBAL input parameters for assessing evapotranspiration and water productivity for the Low-Middle São Francisco River basin, Brazil. Part B: Application to the regional scale. Agricultural and Forest Meteorology, 149(3-4), 477-490. doi: 10.1016/j. agrformet.2008.09.014

Teixeira, A. H. de C., \& Leivas, J. F. (2017). Determinação da produtividade da água com imagens Landsat 8 na região semiárida do Brasil. Conexões - Ciência e Tecnologia, 11(1), 22-34. doi: 10.21439/conexoes. v11i1.1064

Teixeira, A. H. de C., Leivas, J. F., Andrade, R. G., \& Hernandez, F. B. T. (2015). Water productivity assessments with landsat 8 images in the Nilo Coelho irrigation scheme. IRRIGA, 1(2), 1-10. doi: 10.15809/irriga.2015v1n2p01

Toureiro, C., Serralheiro, R., Shahidian, S., \& Sousa, A. (2017). Irrigation management with remote sensing: evaluating irrigation requirement for maize under Mediterranean climate condition. Agricultural Water Management, 184(4), 211-220. doi: 10.1016/j. agwat.2016.02.010

Wang, N., Wang, E., Wang, J., Zhang, J., Zheng, B., Huang, Y., \& Tan, M. (2018). Modelling maize phenology, biomass growth and yield under contrasting temperature conditions. Agricultural and Forest Meteorology, 250-251(2017), 319-329. doi: 10.1016/j.agrformet.2018.01.005

Wu, X., Wen, J., Xiao, Q., Yu, Y., You, D., \& Hueni, A. (2017). Assessment of NPP VIIRS Albedo over heterogeneous crop land in Northern China. Journal of Geophysical Research: Atmospheres, 122(24), 13,138-154. doi: 10.1002/2017JD027262

Yan, W., \& Hunt, L. A. (1999). An equation for modelling the temperature response of plants using only the cardinal temperatures. Annals of Botany, 84(5), 607614. doi: 10.1006/anbo.1999.0955

Yuan, M., Zhang, L., Gou, F., Su, Z., Spiertz, J. H. J., \& Van Der Werf, W. (2013). Assessment of crop growth and water productivity for five C3 species in semi-arid Inner Mongolia. Agricultural Water Management, 122(5), 28-38. doi: 10.1016/j.agwat.2013.02.006 
